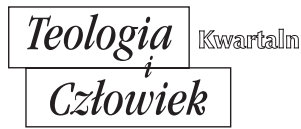

Wydziału Teologicznego UMK

ISSN 1731-5638 (print) ISSN 2391-7598 (online)

(c) (i) $\odot$

54(2021)2, ss. $63-75$

ROBERT ARTUR WARCHAt

UNIWERSYTET PAPIESKI JANA PAWŁA II W KRAKOWIE

PAULINAWARCHAL@INTERIA.PL

ORCID: 0000-0002-9573-3818

\title{
DE PULCHRA, PAX OMNIUM RERUM TRANQUILLITAS ORDINIS. PRZYCZYNKI DO ESTETYKI ŚW. AUGUSTYNA
}

DOI: http://dx.doi.org/10.12775/TiCz.2021.011

Streszczenie. Niniejszy artykuł miał na celu odpowiedź na fundamentalne pytanie dotyczące sposobu istnienia idei w epistemologii Augustyna oraz zaznajomienie czytelnika z niektórymi (współczesnymi) interpretacjami tego zagadnienia. Autor, budując podstawy dla średniowiecznej teorii powszechników, czerpał z tradycji starożytnej oraz Biblii, w tym odnosił się do rozważań z zakresu ówczesnej astronomii, kosmologii i matematyki. Myśliciel z Tagasty określił idee jako niezmienne formy rzeczy. W jego ocenie całe stworzenie nosi pewien ślad podobieństwa względem Boga, co w konsekwencji przekłada się na pogląd, że każdy byt stanowi większą lub mniejszą realizację prawideł odnoszących się do uniwersalnego sposobu istnienia res intelligibiles. Wobec powyższego założenia ciekawie przedstawia się Augustyńska teoria piękna. Autor utrzymuje jej obiektywność obok innych transcendentalnych właściwości bytu: jedność, równość, liczba, rytm, proporcja i porządek są głównymi elementami jego estetyki. Szczególne znaczenie tej doktryny polega na tym, że niematerialne idee umożliwiają osiągnięcie doskonałości życia duchowego, a co za tym idzie, zbliżają nas do Boga, który dla Augustyna jest pierwszym artystą, a zarazem swoistym pryncypium dzieła stworzenia.

Słowa kluczowe: św. Augustyn; byt; idea; estetyka; człowiek; dusza.

Abstract. De Pulchra, pax omnium rerum tranquillitas ordinis. Contributions to the Aesthetics of St. Augustine. The following article aims to resolve the fundamen- 
tal question referring to the way ideas exist in Augustine's epistemology and also to familiarize the reader with contemporary interpretations of this issue. When framing his objectivist theory, Augustine drew on ancient traditions and the Bible, referring to deliberations on astronomy, cosmology and maths among others. The thinker of Thagaste defined ideas as unalterable forms of things. In his view, all creation bears a certain trace of resemblance to God. That leads to a conclusion in the light of which every being is a greater or lesser implementation of the rules of res intelligibiles. In view of the aforementioned assumption, the question of beauty seems interesting. The author upholds its objectivity alongside other transcendental properties of being. Unity, equality, number, rhythm, proportion and order constitute the core elements of his aesthetics. The significance of Augustine's doctrine lies in the fact that immaterial ideas enable achieving perfection in spiritual life, and hence bring us closer to the Creator.

Keywords: St. Augustine, being; aesthetics; human; idea; soul.

Zagadnienie idei było dla Augustyna tematem niezwykle istotnym zarówno od strony teoretycznej, jak i praktycznej. Nic więc dziwnego, że ta problematyka wciąż interesuje badaczy, którzy nie wyrażają $\mathrm{w}$ tej kwestii jednomyślnego stanowiska. Spór dotyczący powszechników odbił się echem przede wszystkim w średniowieczu w związku z różnymi kwestiami teologicznymi, ale aktualny jest i dziś, choć w nieco zmienionej postaci. Na ten temat obszernie wypowiadali się B. Kälin ${ }^{1}$, J. Mausbach ${ }^{2}$, J. Hessen ${ }^{3}$, M. Grabmann oraz R. Teske .

Mówiąc o realnym istnieniu niezmiennych prawideł, nie sposób jest pominąć tego, że w ocenie Augustyna idee wytworzone w ludzkim umyśle nie mają tego samego charakteru, co Boże myśli. Autor w mniejszym stopniu uwzględnia tworzenie się pojęć niż wyjaśnianie znaczenia prawd ogólnych. W jego teorii nie ma problemu uniwersaliów czy choćby kontrowersji wynikającej z rozważań J. Locke’a i G. W. Leibniza. Innymi słowy, Augustyn nie miał potrzeby tłumaczenia natury powszechników. Powstaje pytanie, na które sam autor nie odpowiada w sposób bezpo-

1 Por. B. Kälin, Die Erkenntnislehre des hl. Augustinus, Sarnen 1921, s. 64.

${ }^{2}$ Por. J. Mausbach, Die Ethik des heiligen Augustinus, Freiburg 1929, s. 136.

${ }^{3}$ Por. S. Zabielski, Święty Augustyn i fenomenologia. Historycznofilozoficzna analiza stanowiska Jana Hessena w kwestii intuicji augustyńskiej, Lublin 2003, s. 28.

${ }^{4}$ Por. M. Grabmann, Des hl. Augustinus, Quaestio de ideis, Mittelalterliches Geistesleben, Bd. II, München 1936, s. 28-29. 
średni: czym staje się pojęcie w jego doktrynie? Zdaniem É. Gilsona nie znamy w augustynizmie żadnej teorii uogólnienia 5 .

Augustyn rozpatruje omawiane zagadnienie na płaszczyźnie matematyczno-noetycznej. O twierdzeniach odnoszących się do arytmetyki stwierdza:

Jednemu przychodzi to łatwiej, drugiemu trudniej, inny jeszcze w ogóle nie może podołać. A tymczasem ona sama $\mathrm{w}$ równej mierze udziela się wszystkim, którzy są zdolni ją pojąć [...]. Nie było i nie będzie takiego czasu, żeby siedem i trzy nie tworzyło dziesięciu. Jak powiedziałem, ta niezniszczalna prawdziwość stosunków liczbowych jest wspólna dla mnie i dla każdego, kto rozumuje ${ }^{6}$.

Jak słusznie zauważa J. Brudz, niektóre $\mathrm{z}$ tych prawideł trwają stale w naszym umyśle 7 . Nie chodzi tutaj rzecz jasna o wieczność sensu stricto, jakoby idee posiadały nieskończone istnienie bez początku ani końca, lecz o szersze rozumienie odnoszące się do ich niezmienności ${ }^{8}$. Dla Augustyna prawda zawarta w stosunkach liczbowych nie należy do dziedziny zmysłowego poznania, gdyż oglądanie jej przysługuje wspólnie wszystkim ludziom9 ${ }^{9}$ Oczywiście, człowiek może dojść do pewnych twierdzeń poprzez empirię, ale ich ogólność pozostaje zawsze transcendentna względem odbiorcy, innymi słowy brak poznania zmysłowego nie może wpłynąć na prawdziwość sądów wynikających z arytmetyki.

Powyższe poglądy wydają się uzasadnione, zwłaszcza gdy uwzględnimy wypowiedzi samego autora, który określa idee poprzez res intelligibiles (umysłowe rzeczywistości). W jednym z dzieł Augustyn oznajmia:

${ }^{5}$ Por. É. Gilson, Wprowadzenie do nauki świętego Augustyna, tłum. Z. Jakimiak, Warszawa 1953, s. 144.

${ }^{6}$ Święty Augustyn, O wolnej woli, II, VIII-20, w: tegoż, Dialogi i pisma filozoficzne, t. 3, tłum. A. Trombala, Warszawa 1953, s. 131-132.

7 Por. J. Brudz, Dowód św. Augustyna na istnienie Boga z prawd wiecznych, w: Alma Mater Tarnoviensis: księga pamiątkowa z okazji 150 rocznicy założenia Instytutu Teologicznego i Seminarium Duchownego w Tarnowie (1821-1971), red. P. Bednarczyk, F. Gawlik, Tarnów 1972, s. 106.

8 Por. tamże.

9 Por. tamże, II, VIII-24, s. 135. 
W odróżnieniu od przedmiotów postrzegalnych zmysłami i rozciągłych przestrzennie, idee, byty umysłowe i niematerialne istnieją niezależnie od wszelkiej rozciągłości przestrzennej, a nawet zmian czasowych. Trwają one niezależnie od biegu czasu, niezmiennie, jako byty poznawalne umysłowo, a nie zmysłowo ${ }^{10}$.

Dobrze zrozumiał to stanowisko wspomniany nieco wcześniej M. Grabmann. Niemiecki teolog słusznie podkreślał, że Augustyn nie był pierwszym myślicielem, który umiejscowił odwieczne prawidła w umyśle Boga. Podobną koncepcję przedstawił już wcześniej Filon, mówiąc, że świat idei ma miejsce $\mathrm{w}$ boskim Logosie ${ }^{11}$.

W pismach Hippończyka odnajdujemy bogate nazewnictwo, za pomocą którego autor określa to zagadnienie. Najczęściej posługuje się on pojęciami: ideae, formae oraz species. $\mathrm{Z}$ wypowiedzi Augustyna jasno wynika, że idee są niezmienne i konieczne ${ }^{12}$. Powyższa koncepcja została uargumentowana tym, że res intelligibiles uczestniczą bezpośrednio w samej naturze Boga ${ }^{13}$. Zdaniem biskupa $\mathrm{z}$ Hippony wzorce i formy rzeczy są transcendentne względem osoby ludzkiej, co w konsekwencji przekłada się na pogląd, że człowiek nie ma wpływu na ich naturę. Powyższa interpretacja jest uzasadniona, zwłaszcza gdy uwzględnimy wypowiedzi niektórych badaczy. Na szczególną uwagę zasługuje komentarz F. Coplestona, który pisze:

I znowu, jak liczba matematyczna zaczyna się od jedności i kończy na liczbie, która sama jest jakąś liczbą całkowitą, tak hierarchia bytów rozpoczyna się od najwyższej Jedności, od Boga, który powołuje do istnienia i znajduje swoje odbicie w mniej lub bardziej doskonałych jednostkach ${ }^{14}$.

${ }^{10}$ Święty Augustyn, O Trójcy Świętej, XII, XIV, 23, tłum. M. Stokowska, Kraków 1996, s. 376.

11 Por. S. Zabielski, dz. cyt., s. 32.

12 Święty Augustyn, Księga osiemdziesięciu trzech kwestii, 46, 2, przeł., komentarzami opatrzyła I. Radziejowska, Kęty 2012, s. 83.

13 Por. tamże, s. 85.

${ }^{14}$ F. Copleston, Historia filozofii, t. 2: Od Augustyna do Szkota, przeł. S. Zalewski, Warszawa 2000, s. 93. 
Nie chodzi tu rzecz jasna o widzenie samych idei, albowiem ich poznanie nie jest bezpośrednim oglądem Boga. Jak słusznie wspomina F. Körner poznanie tych wzorców dochodzi do skutku dzięki myśli skupiającej się na sobie ${ }^{15}$. Wobec tego próżno jest doszukiwać się w poglądach biskupa z Hippony zasady esse est percipi. Takie stanowisko może przypominać niektóre założenia idealizmu subiektywnego, zakładającego także w zewnętrznym, przedmiotowym poznaniu formy narzucane doświadczeniu przez uwarunkowania samego podmiotu. Obszerniejsze rozwinięcie tego wątku zostanie zawarte w jednym z dzieł G. Berkeleya, gdzie wiedza refleksyjna, podobnie jak u Augustyna, zostaje odseparowana od rozpoznania przedmiotowego ${ }^{16}$. Co prawda, możemy przyjąć, że wrażenie jest wytworem duszy, ale tylko w takim założeniu, że jego przyczyna znajduje się w świecie zewnętrznym ${ }^{17}$. Augustyn dokonuje rozróżnienia poznawanych rzeczy na te, które odkrywamy dzięki pomocy zmysłów ciała oraz umysłowe, dane na drodze intuicji lub rozumu ${ }^{18}$. Wyraźnie stwierdza:

W rzeczy samej, jeżeli człowiek może bez pomocy mistrza odróżnić białe od czarnego, to nie z tej racji, że znał już te barwy zanim jego dusza złączyła się z ciałem... ${ }^{19}$.

Na podstawie powyższej wypowiedzi należy stwierdzić, że jego rozumienie idei nie jest identyczne z platońską teorią reminiscencji. Wynika to stąd, że w filozofii Augustyna poznanie nie oznacza przypominania sobie pierwotnego stanu rzeczy jeszcze przed wcieleniem ${ }^{20}$.

Ciekawe stanowisko na ten temat przedstawił w swojej pracy J. Brudz. Ujęcie, które proponuje autor, różni się od dotychczasowych. $\mathrm{Z}$ jego określenia wynika bowiem, że niektóre prawidła mogą być wytworem człowieka. Według słów autora:

\footnotetext{
15 Por. S. Zabielski, dz. cyt., s. 37.

16 Zob. George Berkeley, Alkifron, przeł. M. Olszewski, Kęty 2008, s. 255.

17 Por. É. Gilson, dz. cyt., s. 107.

${ }_{18}$ Por. Święty Augustyn, O Trójcy Świętej, XII, XV, 24; XV, XII, 21, s. 377, 488.

19 Tenże, O Trójcy Świętej, XII, XV, 24; s. 377.

20 Por. É. Gilson, dz. cyt., s. 107.
} 
Rozum ludzki ujmuje otaczającą nas rzeczywistość. Czyni to zwykle w sposób prosty, samorzutnie, spontanicznie. Wytworem tej czynności umysłu są pojęcia, czyli idee. Niektóre z nich - rozumuje dalej św. Augustyn - nie powstają w naszym umyśle dopiero wówczas, gdy dostrzegamy dany przedmiot, którego duchowym obrazem jest idea: ani też nie przestają istnieć, gdy dany przedmiot zniknie, lecz trwają nadal w naszym umyśle: nie implikują one bowiem aktualnego istnienia przedmiotu, lecz jedynie wyrażają zgodność istotnych cech pojęcia i przedmiotu ${ }^{21}$.

Punktem wyjścia dla jego rozważań są prawdy wieczne w znaczeniu pojęć oraz sądów. Autor dowodzi, że sposób istnienia idei odbywa się na dwóch płaszczyznach: ontycznej i intelektualnej. Pierwsza z nich przypisuje omawianym wzorcom partycypację w naturze Boga, natomiast druga odnosi się wyłącznie do porządku afirmacyjno-kognitywnego. Zdaniem J. Brudza prawdy wieczne rozumiane jako niezmienne sądy nie mają w filozofii Augustyna podstawy ontologicznej, gdyż istnieją wyłącznie w ludzkiej myśli. Konsekwencją tego poglądu jest uznanie semiologicznej paraleli pomiędzy rolą i właściwością znaku²2.

Powyższe przykłady należy uznać za filozoficzne interpretacje, gdyż w rzeczywistości nie ma u Augustyna sugerowanych podziałów pomiędzy sądami syntetycznymi a obiektywną prawdą będącą podstawowym zagadnieniem religii chrześcijańskiej. Ostatni termin odnosi się do hebrajskiego słowa emet, które jest spokrewnione z wyrazem amen i wskazuje na żywą wiernośćc ${ }^{3}$. Istnieje istotna różnica pomiędzy wzorem odnoszącym się do tego, czym odpowiadający przedmiot powinien być, a prawdą w rozumieniu teologicznym, ponieważ inny punkt wyjścia przyjmuje filozofia, a inny Pismo Święte, które rozumie to pojęcie w sposób bardziej wysublimowany, tj. w osobie Jezusa Chrystusa ${ }^{24}$. Dla podkreślenia swoich racji Augustyn odwołuje się do samoświadomości człowieka oraz bezpośredniego doświadczenia, jego zdaniem dusza może osiągnąć Boga przez akt myślowy, gdyż prawda jest dostępna umysłowi ludzkiemu, aczkolwiek jej poznanie odbywa się w sposób wielowymiarowy tj. poprzez zaangażowanie umysłu,

${ }^{21}$ J. Brudz, dz. cyt., s. 103-104.

${ }^{22}$ Por. tamże, s. 108.

${ }^{23}$ Por. Leksykon pojęć teologicznych i kościelnych, przeł. J. Ożóg, B. Żak, Kraków 2002, s. 256.

${ }^{24}$ Zob. J 1,14; J 3,21. 
serca i woli ${ }^{25}$. Z tej zasady filozof wyciąga interesujące wnioski, w świetle których omawiane zagadnienie zostanie określone w kategoriach chrystologicznych. Dobitnie stwierdza:

Aby zaś w tej wierze z większą pewnością dusza kroczyć mogła ku prawdzie, więc samaż prawda, Bóg, Syn Boży, przyjąwszy człowieczeństwo, a bóstwa nie straciwszy, wiarę tę określił i ugruntował, aby człek miał do swego Boga drogę wskazaną przez człowieka - Boga ${ }^{26}$.

Analiza twórczości Augustyna uprawnia do wniosku, iż dochodzimy do poznania prawd koniecznych i niezmiennych pod wpływem działania arcybytu, który sam posiada te cechy w sposób nieodzowny. W jego ocenie idee nie są realnie jakąś wielością, którą można odnieść do samoistnych rzeczy. Chrześcijański pisarz, prowadząc swoje rozważania, akcentuje uniwersalny charakter prawideł, które odnoszą się do porządku kognitywnego, wychodząc niejako naprzeciw umysłowej naturze człowieka. W rezultacie da się je odwzorować w pewnym typie stworzenia, ale nie w sposób zupełny, gdyż - jak pamiętamy - wgląd w ich niezmienną naturę nie oznacza, że poznajemy bezpośrednio Bożą istotę. Słuszne jest twierdzenie, że dla Augustyna te pojęcia są podstawowymi nośnikami prawdy teologicznej.

Problematyka piękna jest dla biskupa z Hippony tematem drugoplanowym i nie stanowi w jego filozofii celu nadrzędnego. Należy jednak zwrócić uwagę na to, że Augustyn nie odrzuca rozważań natury czysto estetycznej, tzn. omawia to zagadnienie w różnych aspektach, wśród nich porusza tematykę liczby, podobieństwa, równości, proporcji, harmonii i porządku, łącząc je z doświadczeniem egzystencjalnym. Odniesienie do prawideł matematyki posiada specyfikę poniekąd mniej teologiczną, co oznacza, że autor zajmował się nią jeszcze w okresie przedchrześcijańskim ${ }^{27}$.

25 Por. J. Brudz, dz. cyt., s. 111.

${ }^{26}$ Święty Augustyn, Państwo Boże, XI, II, przeł. ks. W. Kubicki, Warszawa 2002, s. 405 .

${ }^{27}$ Por. W. Tatarkiewicz, Historia estetyki, t. 2: Estetyka średniowieczna, Warszawa 1989, s. 49. 
Podejmując kwestię przeżycia estetycznego, należy stwierdzić jeden bardzo ważny fakt, a mianowicie, że piękno nie pozostaje nigdy na poziomie obrazu, lecz odnosi się do świadomości oraz działania umysłu, który nadaje zmysłom określoną treśćc ${ }^{28}$. W swoich poglądach autor łączy platońską ideę piękna z biblijną egzegezą odmiennego statusu zachodzącego pomiędzy Stwórcą a odtwórcą ${ }^{29}$. W tym kontekście Jan Paweł II wspomina o tym, że Boże działanie jest właściwe wyłącznie Wszechmogącemu, natomiast artysta wykorzystuje coś, co już istnieje i czemu on nadaje formę oraz znaczenie ${ }^{30}$. Zatem omawiany wątek jest dla Augustyna kategorią metafizyczną, gdyż istnieje w sposób obiektywny.

Liczne wypowiedzi myśliciela z Tagasty wskazują na to, że zasadniczymi cechami piękna są jedność oraz pojęcie harmonii. Wszystkie inne przymioty formalne pozostają jedynie pewnymi aspektami, ale tylko $\mathrm{w}$ takim zakresie, w jakim powodują one jednolitość w oglądanym obiekcie. $\mathrm{W}$ jednym $\mathrm{z}$ dialogów autor pisze:

We wszystkich umiejętnościach ceni się zgodność, która jest podstawą trwałości i piękna we wszystkim. Zgodność zaś sama dąży do równości i jedności już to przez podobieństwo równych części, już to przez stopniowanie nierównych ${ }^{31}$.

W tej wypowiedzi działanie umysłowe zostało sklasyfikowane za pomocą kategorii odniesienia i proporcji, a więc wzajemnej harmonii poszczególnych elementów.

Biskup z Hippony podejmuje próbę określenia wartości estetycznej, w tym celu odwołuje się do Biblii oraz osobistego doświadczenia ${ }^{32}$. W jego ocenie właściwie dobrane kształty oraz ich zgodność przemawiają na korzyść oglądanego zjawiska. Według tego stanu rzeczy jedność jest formą wszelkiej piękności, stąd może zdarzyć się tak, że o ocenie przedstawianej

${ }^{28}$ Zob. J. P. Manoussakis, Theophany and Indication, Reconciling Augustinian and Palamite Aesthetics, "Modern Theology" 26 (2009) 1, s. 77.

${ }^{29}$ Por. Święty Augustyn, O wierze prawdziwej, XXXII-59, w: tegoż, Dialogi i pisma filozoficzne, tłum. J. Ptaszyński, Warszawa 1954, t. 4, s. 122.

${ }^{30}$ Por. Jan Paweł II, List Ojca świętego Jana Pawła II do Artystów, Watykan 1999, s. 4-5.

31 Święty Augustyn, O wierze prawdziwej, XXX-55, s. 118.

32 Por. tamże, XLI-77, s. 135. 
wartości nie zadecyduje jedna część, lecz ich wzajemny stosunek. Wygląda więc na to, że pojęcie miary i liczb nie jest dla autora zasadą sensu stricto $^{33}$. Powyższa myśl dotyczy nie tylko tego, co rozumiemy pod pojęciem widzialnego obrazu, lecz również jakości symfonicznej oraz poezji3i ${ }^{3}$. To stanowisko wpisuje się w teorię transcendentaliów w takim znaczeniu, że człowiek nigdy nie wyczerpie wartości związanych z obliczem piękna, które nie pozostaje subiektywnym przeżyciem indywidualnej jednostki, lecz stanowi rzeczywistość umysłową i obiektywną.

Według Biblii świat traktowany jest jako Opus Dei, będący zarazem pierwszym dziełem sztuki. Nie ulega wątpliwości, że Augustyn, rozważając omawiane zagadnienia, korzystał nie tylko z dorobku Pisma Świętego, ale odwoływał się również do filozofii starożytnej, zwłaszcza do myśli pitagorejczyków oraz doktryny Platona ${ }^{35}$. W swojej filozofii łączy on doświadczenie piękna z platońskim rozumieniem triady, w której trzy nierozłączne elementy (prawda, dobro i piękno) stanowią jedną rzeczywistość. Jednak w przeciwieństwie do poglądów greckiego filozofa, Augustyn wykazuje, że idea dobra może wynieść duszę człowieka na poziom ewangelicznej cnoty wyrażonej w biblijnych pouczeniach.

W swoich pismach autor próbuje określić estetykę matematyczną za pomocą odpowiedniego ładu oraz odniesienia poszczególnych części ${ }^{36}$. Przecież starożytna teoria $\tilde{\varepsilon} v \omega \sigma \iota \varsigma$ polega na zrozumieniu pewnych wzorców, których ocena nie jest prostym odzwierciedleniem rzeczywistości danej zmysłowo, ale niesie ze sobą zawsze konkretne znaczenie, które można określić jako egzystencjalno-fenomenologiczne. Tak rozumiane zagadnienie jest przedmiotem całej Augustyńskiej estetyki. Filozof dostrzegł w pojęciu jedności archetyp wszelkiego piękna, jednak nie w znaczeniu noetycznego redukcjonizmu, gdyż wartość stworzenia pozostaje zawsze stosunkiem pośledniejszym względem Stwórcy.

Charakterystyczne dla jego myśli jest również to, że piękno dostrzegamy poprzez ideę porządku, nie chodzi jednak wyłącznie o odczucia

${ }^{33}$ Por. Święty Augustyn, O porządku, II, XV-42, w: tegoż, Dialogi i pisma filozoficzne, t. 1, tłum. J. Modrzejewski, Warszawa 1953, s. 215.

${ }^{34}$ Zob. tenże, O muzyce, XII-34, w: tegoż, Dialogi i pisma filozoficzne, t. 4, tłum. D. Turkowska, Warszawa 1954, s. 53. Por. tenże, O wolnej woli, II, XVI-42, s. 153.

35 Por. W. Tatarkiewicz, dz. cyt., s. 50.

36 Por. Święty Augustyn, O muzyce, XIII-38, s. 56. 
wąsko pojętej empirii, lecz przede wszystkim o przeżycie, które posiada specyfikę epistemiczną, odnoszącą się do sfery ludzkich sądów, abstrakcji, a także intuicji ${ }^{37}$. Tak rozumiane zagadnienie stanowi o różnicy przeciwieństw. Myśliciel z Tagasty przytacza tę regułę, gdy pisze: „Tak to piękno wszechrzeczy wyrasta niejako z przeciwieństw - co i w dyskusji sprawia nam przyjemność - czyli ze sprzeczności" ${ }^{38}$. Zagadnienie odpowiedniości definiuje stosunek antytezy ze względu na użyteczność, ponieważ ta sama rzecz może być odpowiednia dla jednego celu, a nieodpowiednia dla innego ${ }^{39}$. Odmienność oraz kontrast mogą także decydować o pięknie świata zbudowanego z przeciwieństw. Czynnik umysłowy, konsolidując ludzką wyobraźnię, umożliwia właściwe rozpoznanie przyczyny odrębności. Chrześcijański pisarz rozróżnia w przedmiotowej kwestii dwa aspekty: sensytywny oraz noumenologiczny i choć nie pomija on ważnych tematów odnoszących się do kategorii spostrzeżeń, to jednak decydującą rolę odgrywa ten drugi. W dialogu $O$ wierze prawdziwej autor posługuje się następującym przykładem:

Skąd znasz tę jedność, według której wydajesz sąd o ciałach? Przecież gdybyś jej nie widział nie mógłbyśs sądzić, że ciała jej nie osiągają [...]. Jedność tę zatem dostrzegamy myśląa ${ }^{40}$.

Drugą ważną kwestią w doświadczeniu estetycznym jest moment wolitywno-egzystencjalny. Kognitywny ogląd rzeczy umysłowych res intelligibiles angażuje nie tylko wolę odbiorcy, lecz posiada także dodatkowy walor, a mianowicie ontologiczny sposób istnienia. Propozycja Augustyna przekracza wszelki subiektywny horyzont interpretacji, co oznacza, że piękno nie jest wyłącznie tworem i konstrukcją myśli. Owszem, człowiek tworzy dzieła sztuki, ale tylko w takim znaczeniu, że wpływ na nie ma świat przyrody oraz Bóg. Augustyn pisze o tym w sposób następujący: „Sprawcy i miłośnicy piękności materialnych stamtąd czerpią miarę, według której je oceniają" ${ }^{41}$. W takim rozumieniu przeżycie sztuki wykracza

\footnotetext{
37 Por. tenże, Wyznania, IV, 13, przeł. Z. Kubiak, Warszawa 1987, s. 77.

38 Tenże, O porządku, I, VII-18, s. 161.

39 Por. W. Tatarkiewicz, dz. cyt., s. 52.

40 Święty Augustyn, O wierze prawdziwej, XXXII-60, s. 123.

${ }^{41}$ Tenże, Wyznania, X, 34, s. 257.
} 
poza dualizm podmiotowo-przedmiotowy i jest zwrócone w kierunku idei, która transcenduje doświadczającego. Sposób przeżycia piękna ma jeszcze inną, ale równie ważną właściwość, a mianowicie rytm. Augustyn rozróżnia pięć kategorii, wśród nich opisuje funkcje mowy i śpiewu, a także słuchu, łącząc je $\mathrm{z}$ aktywnością pamięci oraz woli² ${ }^{4}$. Filozof odróżnia wewnętrzną rację działania sądów od domeny spostrzeżenia, te ostatnie określa jako wrodzoną predyspozycję, która wpływa na intelektualną analizę wszystkich pozostałych dźwięków ${ }^{43}$.

Biskup z Hippony nie zaprzeczał temu, że w stworzonym świecie jest miejsce także na to, co określa się mianem brzydoty. Powyższe pojęcie wiąże się u niego ściśle $\mathrm{z}$ teorią teodycei, według której zło nie posiada charakteru pozytywnego, lecz jest jedynie antytezą i brakiem ${ }^{44}$. W ujęciu autora każda rzecz posiada jakieś pozytywne znaczenie, jednak piękno duchowe jest doskonalsze względem materialnego ${ }^{45}$. Przesłanką brzydoty jest więc brak lub odejście od idei piękna. Ta ontologiczna dedukcja w sposób oczywisty dotyczy bytu pośledniejszego, a więc tego, który jest gorszy.

W swoich pismach filozof nie sprowadza wartości sztuki do jednej konkretnej teorii, gdyż, jak zostało wykazane, jego poglądy i zakres rozważań obejmują wiele odrębnych dziedzin wykraczających poza analizowaną problematykę ${ }^{46}$. Treść piękna nie polega jedynie na oglądaniu rzeczy tylko samymi zmysłami, lecz dotyczy przede wszystkim świata aksjologii, w tym zaangażowania takich walorów, jak prawda oraz cno$\operatorname{ta}^{47}$. Kluczowym elementem tej doktryny staje się dążenie do harmonii życia a więc urzeczywistnienia się piękna Bożego w człowieku. Augustyn zaleca: „Ich ozdobą niech będzie nie to, co zewnętrzne [...] ale wnętrze serca człowieka o niezachwianym spokoju i łagodności ducha, co jest tak

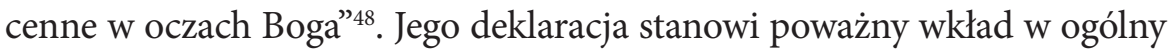
sposób postrzegania ludzkiej natury, w której musica humana staje się

${ }^{42}$ Por. tenże, O muzyce, IV-5, s. 25.

43 Por. W. Tatarkiewicz, dz. cyt., s. 53.

${ }_{44}$ Por. tamże.

45 Por. Święty Augustyn, O wierze prawdziwej, XXXII, 59-60, s. 122-123.

46 Zob. J. Puzio, Teoria poznania zmysłowego u św. Augustyna, Lublin 1947, s. 41.

47 Por. A. Karpowicz-Zbińkowska, Harmonia Bożego dzieła stwórczego $w$ dialogach filozoficznych św. Augustyna, "Studia Theologica Varsaviensia" 44 (2006) 2, s. 83.

481 P 3,3-5. 
antropologią teologiczną wkraczającą w rejony eschatologii, natomiast musica instrumentalis rozciąga pojęcie harmonii na wyższy poziom kontemplacji samego Boga ${ }^{49}$.

\section{BIBLIOGRAFIA}

Berkeley, George, Alkifron, przeł., wstępem i przypisami opatrzył M. Olszewski, Biblioteka Europejska, Wydawnictwo Marek Derewiecki, Antyk, Kęty 2008.

Biblia Tysiąclecia, Wydawnictwo Pallottinum, Poznań 2012.

Brudz, Józef, Dowód św. Augustyna na istnienie Boga z prawd wiecznych w: Alma Mater Tarnoviensis: księga pamiątkowa z okazji 150 rocznicy założenia Instytutu Teologicznego i Seminarium Duchownego w Tarnowie (1821-1971), red. P. Bednarczyk, F. Gawlik, Tarnów 1972, s. 103-115.

Copleston, Frederick, Historia filozofii, t. II: Od Augustyna do Szkota, przeł. S. Zalewski, Inst. Wydawniczy PAX, Warszawa 2000.

Gilson, Étienne, Wprowadzenie do nauki świętego Augustyna, tłum. Z. Jakimiak, Instytut Wydawniczy PAX, Warszawa 1953.

Grabmann, Martin, Des hl. Augustinus, Quaestio de ideis, Mittelalterliches Geistesleben, Bd. II, München 1936.

Jan Paweł II, List Ojca świętego Jana Pawła II do Artystów, Drukarnia Watykańska, Watykan 1999.

Kälin, Bernard, Die Erkenntnislehre des hl. Augustinus, Sarnen 1921.

Karpowicz-Zbińkowska, Antonina, Harmonia Bożego dzieła stwórczego $w$ dialogach filozoficznych św. Augustyna, "Studia Theologica Varsaviensia" 44 (2006) 2, s. 55-85.

Manoussakis, John P., Theophany and Indication, Reconciling Augustinian and Palamite Aesthetics, "Modern Theology" 26 (2009) 1, s. 76-89.

Mausbach, Joseph, Die Ethik des heiligen Augustinus, Freiburg 1929.

O’Collins, Gerald; Edward G. Farrugia, Leksykon pojęć teologicznych $i$ kościelnych $z$ indeksem angielsko-polskim, przekł. J. Ożóg, B. Żak, wyd. WAM, Kraków 2002.

Puzio, Jan, Teoria poznania zmystowego u św. Augustyna, Lublin 1947.

Św. Augustyn, Księga osiemdziesięciu trzech kwestii, przeł., komentarzami opatrzyła

I. Radziejowska, Wydawnictwo Marek Derewecki, Kęty 2012.

Św. Augustyn, O muzyce w: Dialogi filozoficzne, t. 4, tłum. D. Turkowska, PAX, Warszawa 1953, s. 5-79.

Św. Augustyn, O porządku w: Św. Augustyn, Dialogi filozoficzne t. 1, tłum. J. Modrzejewski, PAX, Warszawa 1953, s. 144-226.

Św. Augustyn, O Trójcy Świętej, tłum. M. Stokowska, wprow. J. Tischner; posł. i przypisy J. M. Szymusiak, Wydawnictwo Znak, Kraków 1996.

${ }^{49}$ Por. A. Karpowicz-Zbińkowska, dz. cyt., s. 84. 
Św. Augustyn, O wierze prawdziwej, w: Dialogi filozoficzne, t. 4, tłum. J. Ptaszyński, PAX, Warszawa 1953, s. 80-159.

Św. Augustyn, O wolnej woli, w: Dialogi filozoficzne, t. 3, tłum. A. Trombala, PAX, Warszawa 1953, s. 71-235.

Św. Augustyn, Państwo Boże, przeł. Wł. Kubicki, wstęp J. Salij, Wydawnictwo Antyk Marek Derewiecki, Kęty 2002.

Św. Augustyn, Wyznania, przeł., opatrzył posłowiem i kalendarium Z. Kubiak, Instytut Wydawniczy PAX, Warszawa 1987.

Tatarkiewicz, Władysław, Historia estetyki, t. 2: Estetyka średniowieczna, Wydawnictwo Arkady, Warszawa 1989.

Zabielski, Stanisław, Święty Augustyn i fenomenologia, Historycznofilozoficzna analiza stanowiska Jana Hessena w kwestii intuicji augustyńskiej, Wydawnictwo Uniwersytetu Marii Curie-Skłodowskiej, Lublin 2003. 